\section{Choice of Adjuvant with Halosulfuron Affects Purple Nutsedge Control and Nursery Crop Tolerance}

\author{
Gary L. McDaniel${ }^{1}$, William E. Klingeman², Willard T. Witte ${ }^{3}$, and \\ Phillip C. Flanagan ${ }^{4}$ \\ Department of Ornamental Horticulture and Landscape Design, University of \\ Tennessee, Knoxville, TN 37996-4500
}

Additional index words. sulfonylurea herbicide, herbicide tolerance, phytotoxicity, nonionic surfactant, organosilicone-based adjuvant, crop oil concentrate, Liriope muscari, Hemerocallis sp., Cyperus rotundus, CYPRO

\begin{abstract}
One-half (18 $\mathrm{g} \cdot \mathrm{ha}^{-1}$ a.i. $)$ and three-fourths $\left(27 \mathrm{~g} \cdot \mathrm{ha}^{-1} \mathrm{a.i}.\right)$ rates of halosulfuron (Manage $^{\circledR}$, MON 12051) were combined with adjuvants and evaluated for effectiveness in controlling purple nutsedge (Cyperus rotundus $\mathrm{L}$.) and for phytotoxic responses exhibited by two kinds of container-grown ornamental plants. Adjuvants included X-77 ${ }^{\circledR}, \mathrm{Scoil}^{\circledR}$, Sun-It II ${ }^{\circledR}$, Action “99” ${ }^{\circledR}$, and Agri-Dex ${ }^{\circledR}$. By 8 weeks after treatment (WAT), halosulfuron combined with X-77 ${ }^{\circledast}$, Agri-Dex ${ }^{\circledR}$, or Action “99"® at the lower halosulfuron rate provided $<90 \%$ purple nutsedge suppression. In contrast, Sun-It II ${ }^{\circledR}$ provided $100 \%$ control when combined with the higher halosulfuron rate. Nutsedge control persisted into the following growing season and halosulfuron combined with either Scoil ${ }^{\circledR}$ or Sun-It II ${ }^{\circledR}$ provided $>97 \%$ suppression of nutsedge tuber production. Growth of liriope [Liriope muscari (Decne.) Bailey 'Big Blue'] was not inhibited by Scoil $^{\circledR}$ or Sun-It II ${ }^{\circledR}$ adjuvants in combination with the low rate of halosulfuron. However, regardless of the rate of halosulfuron or adjuvant used, initial foliar chlorosis was observed in both daylily (Hemerocallis sp. L. 'Stella d'Oro') and liriope. All liriope receiving halosulfuron with X-77 ${ }^{\circledR}$, Scoil ${ }^{\circledR}$, or Sun-It II $^{\circledR}$ adjuvants recovered normal foliage by 8 WAT. By contrast, at 8 WAT some daylily still maintained a degree of foliar discoloration. In addition to chlorosis, all treatments reduced flower number in daylilies. The number of flower scapes produced by liriope was not affected by halosulfuron when in combination with either Sun-It II ${ }^{\circledR}$ or Scoil ${ }^{\circledR}$. The high rate of halosulfuron combined with $\mathrm{X}-77^{\circledR}$ or Action “99" ${ }^{\circledR}$ improved control of purple nutsedge. However, this rate inhibited growth of both species, daylily flower numbers, and scape numbers of liriope, regardless of adjuvant. Chemical names used: halosulfuron (Manage $^{\circledR}$, MON 12051, methyl 5-\{[(4,6-dimethyl-2-pyrimidinyl) amino] carbonylaminosulfonyl\}-3-chloro-1-methyl-1- $H$-pyrozole-4-carboxylate); proprietary blends of $100 \%$ methylated seed oil $\left(\right.$ Scoil $^{\circledR}$ and Sun-It II $^{\circledR}$ ); proprietary blend of $99 \%$ polyalkyleneoxide modified heptamethyl trisiloxane and nonionic surfactants (Action "99" $\left.{ }^{\circledR}\right)$; alkylarylpolyoxyethylene, alkylpolyoxyethelene, fatty acids, glycols, dimethylpolysiloxane, and isopropanol $\left(\mathrm{X}-77^{\circledR}\right)$; proprietary blend of $83 \%$ paraffin-based petroleum oil, with $17 \%$ polyoxyethylate polyol fatty acid ester and polyol fatty ester as nonionic surfactants (Agri-Dex ${ }^{\circledR}$ )
\end{abstract}

Purple nutsedge is limited in distribution to the warmer parts of the southern United States, where the average midwinter air temperatures seldom drop below $-2.2{ }^{\circ} \mathrm{C}$ (Bendixen and Nandihalli, 1987). One of the most common weeds found in southern nursery crops (Dowler, 1994), purple nutsedge forms tubers that are interconnected by rhizomes to form chains of as many as 10 tubers per chain, each having $8-10$ buds. While tuber production is the primary means for purple nutsedge propagation and distribution, some viable true seeds

Received for publication 5 Oct. 2000. Accepted 28 Feb. 2001. The cost of publishing this paper was defrayed in part by the payment of page charges. Under postal regulations, this paper therefore must be hereby marked advertisement solely to indicate this fact.

${ }^{1}$ Professor.

${ }^{2}$ Assistant Professor.

${ }^{3}$ Associate Professor.

${ }^{4}$ Research Associate. nutsedge requires herbicides to be translocated throughout the rhizome and tubers to prevent subsequent regrowth once existing shoots are killed (Hauser, 1962). However, eradication of established nutsedge is frequently accomplished only by costly manual labor. To address the need for effective systemic control, halosulfuron was developed to control nutsedge in turfgrass and agronomic crops, and shows promise for nutsedge control in many nursery crops (Bachman et al., 1995; Hurt and Vencill, 1993; McDaniel et al., 1999; Vencill et al., 1995). Halosulfuron (rates shown are a.i. of herbicide formulation) is a postemergence sulfonylurea herbicide that is actively translocated to the underground vascular system of nutsedge rhizomes (Khan and Molin, 1997). Translocation is imperative because the nutsedge vascular system may stay intact long after aerial shoots have been removed (Hauser, 1962). Halosulfuron was shown to reduce purple nutsedge tuber viability following two applications to heavily infested bermudagrass (Molin et al., 1999). Tuber viability and posttreatment regrowth was rate dependent (18-72 g.ha ${ }^{-1}$ ), with regrowth occurring by $46 \mathrm{~d}$ after treatment by all rates. The failure to completely control well-established tubers was attributed to nontranslocation of herbicide caused either by some tubers not being connected to foliage by viable rhizomes or through an interrupted rhizomal connection that existed between tubers.

In warm and cool season turfgrasses, purple nutsedge control was $>85 \%$ with halosulfuron rates $\leq 0.071 \mathrm{~kg} \cdot \mathrm{ha}^{-1}$ (Ross and Lembi, 1985). No growth reduction or phytotoxicity to the turf species was observed. Hurt and Vencill (1994) reported that at $28 \mathrm{~d}$ after treatment (DAT), over-the-top halosulfuron applications to green liriope at rates $\leq 0.018 \mathrm{~kg} \cdot \mathrm{ha}^{-1}$, resulted in no observable phytotoxicity. They did, however, report halosulfuron injury to new growth of 'Macrantha Orange' azalea (Rhododendron xindicum 'Macrantha Orange') at 0.009 and $0.018 \mathrm{~kg} \cdot \mathrm{ha}^{-1}$ rates by 28 DAT. In a separate study, Bachman et al. (1995) found that halosulfuron at 0.071-0.28 $\mathrm{kg} \cdot \mathrm{ha}^{-1}$ also caused growth reductions in cotoneaster (Cotoneaster dammeri C.K. Schneid. 'Coral Beauty') and 'Hetz Blue' Chinese Juniper (Juniperus chinensis L. 'Hetzi Glauca'). Although no foliar symptoms were observed on Chinese juniper, shoot tips were killed on cotoneaster and foliar discoloration occurred on crape myrtle (Lagerstroemia indica L. 'Carolina Beauty') at all halosulfuron rates tested.

Choice of adjuvants may alter the effectiveness of some herbicides (Harrison et al., 1986; McWhorter, 1992; Nalewag et al., 1986) or may influence crop plant tolerance. Petroleum oil and petroleum oil-based adjuvants increase cuticular absorption and uptake of pesticides, but also increase the potential for phytotoxicity to crop plants (Johnson, 1985) and reduced physiological parameters (Helson and Minshall, 1962; Reihl and Wedding, 1959; Wedding and Riehl, 1951). Soybean oil, when applied with Fusilade ${ }^{\circledR}$ \{fluazifop-butyl, Butyl (R)-2-[4-[[5-(trifluoromethyl)-2-pyridinyl]- 
oxy]phenoxy]propanoate $\}$ to soybean [Glycine $\max (\mathrm{L}$.) Merr.] was shown to provide the same benefit as petroleum oils used as an adjuvant, but caused less phytotoxic damage to the crop plants (Cantwell and Kapustra, 1986). Banks and Oliver (1984) reported that, with some postemergence herbicides, spray volumes could be reduced and weed control could be maintained or improved if soybean oil plus water was used as a carrier. Soybean oil has also been shown to have insecticidal activity as dormant oil sprays to fruit trees, but no phytotoxicity or plant growth parameters were reported (Hix et al., 1999). McDaniel et al. (1999) reported that $>90 \%$ control of yellow nutsedge in container landscape plants was achieved with late-spring applications of halosulfuron at $18 \mathrm{~g} \cdot \mathrm{ha}^{-1}$ combined with $0.5 \%$ $(\mathrm{v} / \mathrm{v})$ rate of either the soybean crop oil Scoil ${ }^{\circledR}$, or the sunflower (Helianthus annuus L.) crop oil Sun-It II ${ }^{\circledR}$. Halosulfuron mixed with $0.5 \%$ Sun-It II ${ }^{\circledR}$ resulted in no phytotoxicity or growth reduction to 'Big Blue' liriope, 'Blue Girl' holly (Ilex ×meserveae S.Y. Hu 'Blue Girl'), or Japanese holly (I. crenata Thunb. 'Bennett's Compacta').

Used with a postemergence herbicide like halosulfuron, the adjuvant and concentration selected can influence retention of spray solutions, enhance entry into foliage and increase herbicide efficacy on target weed species. Conversely, improper choice of adjuvant may result in phytotoxicity to desirable ornamental species. These concerns initiated a comparison of nonionic, paraffin-based crop oil, soybean oil, sunflower oil, and organosilicone surfactants in combination with halosulfuron, which was applied at reduced rates. Experimental criteria included: 1) the extent of purple nutsedge suppression; 2) an evaluation of growth and phyto- toxicity to two container-grown ornamental species; and 3) carry-over effects of treatments on flowering and survival of purple nutsedge during the following summer.

\section{Materials and Methods}

'Big Blue' liriope was planted into 3.8-L containers and 'Stella d'Oro' daylily was potted into 11.4-L containers using a soilless medium consisting of 4 ground pine bark : 1 ProMix BX ${ }^{\circledast}$ (Premier Horticulture, Redhill, $\mathrm{Pa}$.) peat-based growing $\operatorname{mix}(\mathrm{v} / \mathrm{v})$. The medium was amended with $4.2 \mathrm{~kg} \cdot \mathrm{m}^{-3}$ of dolomitic lime, $1.2 \mathrm{~kg} \cdot \mathrm{m}^{-3}$ of triple superphosphate $0 \mathrm{~N}-20.2 \mathrm{P}$ $0 \mathrm{~K}, 1.4 \mathrm{~kg} \cdot \mathrm{m}^{-3}$ of gypsum, and $0.9 \mathrm{~kg} \cdot \mathrm{m}^{-3}$ of

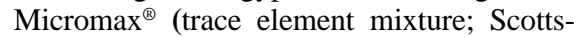
Sierra Horticultural Products Co., Marysville, Ohio). Each crop species was inoculated with 5 sprouted purple nutsedge tubers per pot in May 1999. Following nutsedge inoculation, liriope were topdressed with Osmocote ${ }^{\circledR}$ 14N-6.2P-11.6K (Scotts-Sierra) at $5 \mathrm{~g} / \mathrm{con}$ tainer and daylily at $20 \mathrm{~g} /$ container. Supplemental weekly fertilization of Peters ${ }^{\circledR}$ General Purpose soluble fertilizer $20 \mathrm{~N}-8.8 \mathrm{P}-16.6 \mathrm{~K}$ (Scotts-Sierra) at $100 \mathrm{mg} \cdot \mathrm{L}^{-1} \mathrm{~N}$ was made for the first 3 weeks during establishment.

Herbicide treatments consisted of halosulfuron herbicide (Manage ${ }^{\circledR}$; Monsanto, St. Louis) at either $18 \mathrm{~g} \cdot \mathrm{ha}^{-1}$ or $27 \mathrm{~g} \cdot \mathrm{ha}^{-1}$, which were one-half and three-fourths of the lowest rate $\left(31 \mathrm{~g} \cdot \mathrm{ha}^{-1}\right)$ recommended for spot-treatment control of nutsedge. Treatments were used in combination with the following adjuvants: $0.25 \%(\mathrm{v} / \mathrm{v}) \mathrm{X}-77^{\circledR}$ (nonionic spreaderactivator; Loveland Industries, Greeley, Colo.), $1.0 \%(\mathrm{v} / \mathrm{v}) \mathrm{Scoil}^{\circledR}$ (methylated soybean seed oil; AGSCO, Grand Forks, S.D.), 1.0\% (v/v) Sun-It II ${ }^{\circledR}$ (methylated sunflower seed oil;
AGSCO), $1.0 \%$ (v/v) Action "99" ${ }^{\circledR}$ (nonionic organosilicone; Universal Cooperatives, Minneapolis), and $1.0 \%$ (v/v) Agri-Dex ${ }^{\circledR}$ (paraffin crop oil concentrate; Helena Chemical Co., Memphis, Tenn.). Nutsedge control containers, which were manually kept fee of weeds except purple nutsedge, received only water and were not exposed to either herbicide or surfactants. An herbicide control consisted of halosulfuron alone at each rate, without surfactants. Nontreated control plants received only water and were kept weed-free by hand cultivation. Treatments were applied when nutsedge was at a height of 10-15 cm, 5 weeks after tuber inoculation. Environmental conditions present at the time of treatments were: $45 \%$ cloud cover, $28{ }^{\circ} \mathrm{C}, 82 \%$ relative humidity (RH), which changed to $20 \%$ cloud cover, $30{ }^{\circ} \mathrm{C}$, and $87 \% \mathrm{RH}$ by mid-afternoon. The herbicide and surfactant mixtures were applied from above the plants with a $\mathrm{CO}_{2}$ pressurized backpack sprayer delivering $230{\mathrm{~L} \cdot \mathrm{ha}^{-1}}$ through a single $8003 \mathrm{E}$ TeeJet ${ }^{\circledR}$ even flat-fan nozzle (TeeJet, Spraying Systems Co., Wheaton, Ill.).

In a preliminary study, these surfactants were tested with halosulfuron at $31 \mathrm{~g} \cdot \mathrm{ha}^{-1}$, the manufacturers' lowest recommended rate, on the nursery species used in the present study. Results of that investigation (data not shown) indicated that halosulfuron at the label-recommended rate caused moderate to severe phytotoxic reactions among the test species, so it was determined that lower rates should be evaluated. Because the amount of herbicide active ingredient translocated through foliage to the tuber is critical to purple nutsedge control, two rates were selected $\left(18\right.$ and $\left.27 \mathrm{~g} \cdot \mathrm{ha}^{-1}\right)$ in order to evaluate rate effectiveness when tubers are attached by rhizomes.

Table 1. Influence of halosulfuron and adjuvants on purple nutsedge control, growth, and phytotoxicity on plants of 'Big Blue' liriope and 'Stella d'Oro' daylily.

\begin{tabular}{|c|c|c|c|c|c|c|c|c|c|c|}
\hline \multirow[b]{3}{*}{ Treatment ${ }^{\mathrm{w}}$} & \multirow{3}{*}{$\begin{array}{l}\text { Halosulfuron } \\
\text { rate } \\
\left(\mathrm{g} \cdot \mathrm{ha}^{-1}\right)\end{array}$} & \multirow{3}{*}{$\begin{array}{l}\text { Adjuvant } \\
\text { rate } \\
\%(\mathrm{v} / \mathrm{v})\end{array}$} & \multirow{2}{*}{\multicolumn{2}{|c|}{$\begin{array}{l}\text { Purple nutsedge } \\
\text { control }(\%)^{2}\end{array}$}} & \multirow{2}{*}{\multicolumn{2}{|c|}{$\begin{array}{c}\text { Growth index }(\mathrm{cm}) \\
\text { at } 8 \mathrm{WAT}^{\mathrm{y}}\end{array}$}} & \multicolumn{4}{|c|}{ Visual rating $^{\mathrm{x}}$} \\
\hline & & & & & & & \multicolumn{2}{|c|}{ Liriope } & \multicolumn{2}{|c|}{ Daylily } \\
\hline & & & $4 \mathrm{WAT}$ & $8 \mathrm{WAT}$ & Liriope & Daylily & $4 \mathrm{WAT}$ & $8 \mathrm{WAT}$ & $4 \mathrm{WAT}$ & $8 \mathrm{WAT}$ \\
\hline Nontreated Control & 0 & 0 & $100 a^{v}$ & $100 \mathrm{a}$ & $17.9 \mathrm{a}$ & $13.4 \mathrm{a}$ & $0 \mathrm{a}$ & $0 \mathrm{a}$ & $0 \mathrm{a}$ & $0 \mathrm{a}$ \\
\hline Nutsedge Control & 0 & 0 & $0 \mathrm{~g}$ & $0 \mathrm{~g}$ & $13.3 \mathrm{c}$ & $11.7 \mathrm{~b}$ & $0 \mathrm{a}$ & $0 \mathrm{a}$ & $0 \mathrm{a}$ & $0 \mathrm{a}$ \\
\hline Halosulfuron $(\mathrm{H})$ alone & 18 & 0 & $40 \mathrm{f}$ & $18 \mathrm{f}$ & $15.8 \mathrm{a}$ & $12.2 \mathrm{a}$ & $8.0 \mathrm{~b}$ & $2.5 \mathrm{a}$ & $12.8 \mathrm{~b}$ & $1.8 \mathrm{a}$ \\
\hline$H+X-77$ & 18 & 0.25 & $51 \mathrm{e}$ & $70 \mathrm{c}$ & $14.2 \mathrm{c}$ & $11.4 \mathrm{~b}$ & $17.1 \mathrm{c}$ & $2.2 \mathrm{a}$ & $18.1 \mathrm{c}$ & $3.9 \mathrm{a}$ \\
\hline $\mathrm{H}+$ Scoil & 18 & 1.00 & $74 \mathrm{c}$ & $91 \mathrm{ab}$ & $16.9 \mathrm{a}$ & $12.1 \mathrm{ab}$ & $18.4 \mathrm{c}$ & $1.3 \mathrm{a}$ & $20.3 \mathrm{~cd}$ & $11.0 \mathrm{~b}$ \\
\hline $\mathrm{H}+$ Action "99" & 18 & 1.00 & $82 \mathrm{~b}$ & $87 \mathrm{~b}$ & $13.9 \mathrm{c}$ & $8.4 \mathrm{~d}$ & $27.5 \mathrm{~d}$ & $12.8 \mathrm{~b}$ & $42.3 \mathrm{e}$ & $21.6 \mathrm{c}$ \\
\hline $\mathrm{H}+$ Sun-It II & 18 & 1.00 & $80 \mathrm{bc}$ & $97 \mathrm{a}$ & $16.7 \mathrm{a}$ & $12.4 \mathrm{a}$ & $13.4 \mathrm{~b}$ & $2.1 \mathrm{a}$ & $16.3 \mathrm{c}$ & $1.8 \mathrm{a}$ \\
\hline$H+$ Agri-Dex & 18 & 1.00 & $82 \mathrm{~b}$ & $47 \mathrm{~d}$ & $8.7 \mathrm{c}$ & $7.4 \mathrm{c}$ & $29.8 \mathrm{~cd}$ & $15.7 \mathrm{c}$ & $51.4 \mathrm{f}$ & $25.2 \mathrm{~d}$ \\
\hline Halosulfuron $(\mathrm{H})$ alone & 27 & 0 & $55 \mathrm{e}$ & $34 \mathrm{e}$ & $14.7 \mathrm{~b}$ & $11.3 \mathrm{~b}$ & $12.2 \mathrm{c}$ & $3.1 \mathrm{a}$ & $14.3 \mathrm{c}$ & $2.1 \mathrm{a}$ \\
\hline$H+X-77$ & 27 & 0.25 & $65 \mathrm{~d}$ & $86 \mathrm{~b}$ & $13.3 \mathrm{c}$ & $10.1 \mathrm{c}$ & $23.2 \mathrm{~d}$ & $3.0 \mathrm{a}$ & $28.4 \mathrm{~d}$ & $11.2 \mathrm{~b}$ \\
\hline $\mathrm{H}+$ Scoil & 27 & 1.00 & $84 \mathrm{~b}$ & 96 a & $14.3 \mathrm{bc}$ & $11.2 \mathrm{bc}$ & $25.3 \mathrm{~d}$ & $2.6 \mathrm{a}$ & $29.2 \mathrm{~d}$ & $13.4 \mathrm{bc}$ \\
\hline H + Action "99" & 27 & 1.00 & $88 \mathrm{~b}$ & 93 a & $12.3 \mathrm{~d}$ & $4.9 \mathrm{f}$ & $34.6 \mathrm{e}$ & $18.3 \mathrm{~d}$ & $49.8 \mathrm{f}$ & $25.5 \mathrm{~d}$ \\
\hline $\mathrm{H}+$ Sun-It II & 27 & 1.00 & $88 \mathrm{~b}$ & $100 \mathrm{a}$ & $15.2 \mathrm{~b}$ & $11.5 \mathrm{~b}$ & $18.7 \mathrm{c}$ & $2.6 \mathrm{a}$ & $19.8 \mathrm{c}$ & $10.3 \mathrm{~b}$ \\
\hline $\mathrm{H}+$ Agri-Dex & 27 & 1.00 & $87 \mathrm{~b}$ & $58 \mathrm{~d}$ & $6.7 \mathrm{f}$ & $4.7 \mathrm{f}$ & $35.6 \mathrm{e}$ & $19.4 \mathrm{~d}$ & $57.8 \mathrm{f}$ & $29.8 \mathrm{e}$ \\
\hline \multicolumn{11}{|l|}{ Significance $^{u}$} \\
\hline Halosulfuron rate $(\mathrm{H})$ & & & $* *$ & $* *$ & $* *$ & $* *$ & $* *$ & $* *$ & $* *$ & $* *$ \\
\hline Adjuvant (A) & & & $* *$ & $* *$ & $* *$ & $* *$ & $* *$ & $* *$ & $* *$ & $* *$ \\
\hline $\mathrm{H} \times \mathrm{A}$ & & & NS & NS & NS & NS & NS & NS & $* *$ & $* *$ \\
\hline
\end{tabular}

${ }^{2}$ Purple nutsedge control was compared to untreated plants and evaluated on the basis of weed density and vigor on a scale of 0 (no control) to 100 (complete control) at 4 and 8 WAT. Combined data from daylily and liriope were used.

${ }^{y}$ Growth index $=\left(\right.$ height + width $1+$ width $\left._{2}\right) \div 3$, where width ${ }_{2}$ was taken perpendicular to width $_{1}$.

${ }^{x}$ Visual ratings were on a percent scale where $0=$ no damage, $25=$ economically tolerable damage, and $100=$ dead plants. Ratings were taken 4 and 8 weeks after treatment.

${ }^{\text {wH} H a l o s u l f u r o n ~ w a s ~ a p p l i e d ~ a t ~ e i t h e r ~} 18$ or $27 \mathrm{~g} \cdot \mathrm{ha}^{-1}$ to all treatments except nontreated and nutsedge controls. Nontreated control containers were manually kept free of weeds and nutsedge control containers were manually kept free of weeds except purple nutsedge.

"Mean separation in columns by Duncan's new multiple range test, $P \leq 0.05$.

"Significance levels of main effects and interactions are NS $=$ nonsignificant or significant at $P \leq 0.05$ and $\leq 0.01$. 
Purple nutsedge control was compared to untreated plants and evaluated on the basis of nutsedge density on a scale of $0 \%$ (no control) to $100 \%$ (complete control) at 4 and 8 weeks after treatment (WAT). A crop growth index: (height + width $_{1}+$ width $\left._{2}\right) \div 3$, where width $_{2}$ was perpendicular to width $_{1}$, was calculated prior to treatment and $8 \mathrm{WAT}$, with the final index reflecting new growth of the ornamental plants. Growth indices prior to treatment averaged $62.2 \mathrm{~cm}$ for 'Stella d'Oro' daylily and $40.4 \mathrm{~cm}$ for 'Big Blue' liriope. Visual phytotoxicity evaluations were taken 4 WAT and 8 WAT using a scale of $0-100(0=$ no damage, $25=$ pronounced but only temporary discoloration, $50=$ moderate to severe chlorosis with some necrotic foliage, $75=$ severe necrosis and loss of foliage, and $100=$ dead plants). Carry-over effect of treatments were evaluated in the late-spring (daylily) and summer (liriope) of 2000 by determining the number of flowers, number and length of daylily and liriope scapes produced, number of live purple nutsedge tubers, and emerged nutsedge shoots remaining in the containers. Treatments were arranged in a $2 \times 6$ (herbicide rate $\times$ adjuvant) factorial design with 10 single-container replications within each crop species. Data from purple nutsedge control ratings and phytotoxicity ratings were subjected to arc sine square root transformation prior to statistical analysis (Zar, 1984). Data were analyzed for statistical significance using the general linear model (GLM) procedure. Means of significant main effects and interactions were separated using Duncan's new multiple range test at $P \leq 0.05$ (SAS Institute, Cary, N.C.)

\section{Results and Discussion}

Seed-oil-based crop oils (Scoil ${ }^{\circledR}$ and Sun-It II ${ }^{\circledR}$ ) and organosilicone (Action "99"®) adjuvants combined with halosulfuron provided greater control of purple nutsedge 8 WAT than the nonionic $\left(\mathrm{X}-77^{\circledR}\right)$ or paraffin-based crop oil (Agri-Dex ${ }^{\circledR}$ ) adjuvants (Table 1). Halosulfuron, applied alone or combined with Agri-Dex ${ }^{\circledR}$, apparently did not translocate to purple nutsedge rhizomes and tubers, as there was considerable regrowth of plantlets 8 WAT. Halosulfuron (both rates) plus Agri-Dex ${ }^{\circledR}$ also caused immediate chlorosis of purple nutsedge, followed by foliar death by 4 WAT Moreover, halosulfuron at $27 \mathrm{~g} \cdot \mathrm{ha}^{-1}$ plus AgriDex $^{\circledR}$ provided only $58 \%$ purple nutsedge control 8 WAT. Moderate control of nutsedge resulted from halosulfuron at $18 \mathrm{~g} \cdot \mathrm{ha}^{-1}$ with $\mathrm{X}-77^{\circledR}$. Still, the higher rate of halosulfuron with $\mathrm{X}-77^{\circledast}$ provided only $86 \%$ nutsedge control 8 WAT. Use of halosulfuron at 27 g.ha ${ }^{-1}$ in combination with Scoil ${ }^{\circledR}$, Sun-It II ${ }^{\circledR}$, or Agri-Dex ${ }^{\circledR}$ adjuvants provided no additional increases in purple nutsedge control over the lower halosulfuron rate at 8 WAT. Purple nutsedge control was improved only slightly when X-77 ${ }^{\circledR}$ or Action " 99 " ${ }^{\circledR}$ were mixed with halosulfuron at $27 \mathrm{~g} \cdot \mathrm{ha}^{-1} \mathrm{vs}$. halosulfuron at $18 \mathrm{~g} \cdot \mathrm{ha}^{-1}$.

The presence of purple nutsedge affected growth of both ornamental species, where no herbicide or surfactant was applied (Table 1). By 8 WAT, nutsedge alone had inhibited growth of liriope by $26 \%$ and daylily by $13 \%$. In combination with X-77® ${ }^{\circledR}$, Action " 99 ” ${ }^{\circledR}$, or Agri-Dex ${ }^{\circledR}$ adjuvants, halosulfuron at the 18 $\mathrm{g} \cdot \mathrm{ha}^{-1}$ rate inhibited liriope and daylily growth. By contrast, at the lower halosulfuron rate neither Scoil ${ }^{\circledR}$ nor Sun-It II ${ }^{\circledR}$ inhibited growth of these species. Halosulfuron at $27 \mathrm{~g} \cdot \mathrm{ha}^{-1}$ inhibited growth of liriope and daylily, regardless of surfactant used. Daylily was severely stunted by the higher halosulfuron rate combined with either Action " 99 " ${ }^{\circledR}$ (23\% growth reduction) or Agri-Dex ${ }^{\circledR}$ (63\% smaller than control), and by 4 WAT caused the death of some plants in each of these treatments.
Halosulfuron caused initial foliar chlorosis to both species, with or without adjuvant at either herbicide rate (Table 1). Plants treated with halosulfuron combined with $\mathrm{X}-77^{\circledR}$, Scoil ${ }^{\circledR}$, or Sun-It II ${ }^{\circledR}$ adjuvants had recovered significantly by 8 WAT, although daylily still displayed some foliage discoloration. Halosulfuron with Action "99" " caused early foliar chlorosis to liriope and necrosis of treated daylily foliage. By 8 WAT, new growth of liriope exhibited less chlorosis. Agri-Dex ${ }^{\circledast}$ combined with halosulfuron resulted in immediate foliar chlorosis on both species, with foliage becoming severely necrotic by 4 WAT.

Among overwintered daylily, viable purple nutsedge tubers and emerging shoots were evaluated in June 2000 (Table 2). No nutsedge shoot emergence was evident by July 2000 in any liriope treatments. Extensive growth of 'Big Blue' liriope rhizomes and their similar appearance to purple nutsedge tubers limited differentiation; therefore, nutsedge tubers were recovered only from 'Stella d'Oro' daylily. Both rates of halosulfuron combined with either Scoil ${ }^{\circledR}$ or Sun-It II $^{\circledR}$ provided $>97 \%$ suppression of nutsedge tuber survival in daylily. These treatments produced an average of 0-2 shoots/container emerging from surviving tubers. The $27 \mathrm{~g} \cdot \mathrm{ha}^{-1}$ rate of halosulfuron plus $\mathrm{X}-77^{\circledR}$ or Action “99"® suppressed tuber survival $>90 \%$, with 5-9.3 tubers/container remaining viable. Previous studies (Grichar and Sestak, 2000; Jordan, 1996) have demonstrated that the manufacturer's recommended use of a nonionic spreader-activator, such as $\mathrm{X}-77^{\circledR}$, resulted in less purple nutsedge control when mixed with postemergence herbicides than when herbicides are combined with crop oil concentrates or organosilicone-based adjuvants. These results with halosulfuron agree with other reports that adjuvants differ in their enhancement of weed control (Kirkwood,

Table 2. Second year effects of halosulfuron and adjuvants on 'Big Blue' liriope and 'Stella d'Oro' daylily flowering, scape production, and number of nutsedge tubers and emerged shoots.

\begin{tabular}{|c|c|c|c|c|c|c|c|c|c|}
\hline \multirow[b]{2}{*}{ Treatment $^{y}$} & \multirow{2}{*}{$\begin{array}{l}\text { Halosulfuron } \\
\text { rate } \\
\left(\mathrm{g} \cdot \mathrm{ha}^{-1}\right)\end{array}$} & \multirow{2}{*}{$\begin{array}{l}\text { Adjuvant } \\
\text { rate } \\
\%(\mathrm{v} / \mathrm{v})\end{array}$} & \multirow{2}{*}{$\begin{array}{l}\text { No. of } \\
\text { flowers } \\
\text { Daylily }\end{array}$} & \multicolumn{2}{|c|}{$\begin{array}{l}\text { No. of } \\
\text { scapes }\end{array}$} & \multicolumn{2}{|c|}{$\begin{array}{c}\text { Scape } \\
\text { length }(\mathrm{cm})\end{array}$} & \multicolumn{2}{|c|}{$\begin{array}{c}\text { No. of } \\
\text { purple nutsedge } \\
\end{array}$} \\
\hline & & & & Daylily & Liriope & Daylily & Liriope & Tubers & Shoots \\
\hline Nontreated control & 0 & 0 & $58.6 \mathrm{a}^{\mathrm{x}}$ & $11.4 \mathrm{a}$ & $17.2 \mathrm{a}$ & $32.6 \mathrm{~b}$ & $24.8 \mathrm{a}$ & $0 \mathrm{a}$ & $0 \mathrm{a}$ \\
\hline Nutsedge control & 0 & 0 & $26.6 \mathrm{~d}$ & $6.4 \mathrm{~b}$ & $10.6 \mathrm{~b}$ & $34.7 \mathrm{~b}$ & $24.9 \mathrm{a}$ & $79.8 \mathrm{f}$ & $37.6 \mathrm{e}$ \\
\hline Halosulfuron $(\mathrm{H})$ alone & 18 & 0 & $25.0 \mathrm{e}$ & $7.0 \mathrm{~b}$ & $10.2 \mathrm{c}$ & $34.7 \mathrm{~b}$ & $24.2 \mathrm{~b}$ & $24.8 \mathrm{~d}$ & $12.3 \mathrm{c}$ \\
\hline$H+X-77$ & 18 & 0.25 & $31.0 \mathrm{~d}$ & $6.4 \mathrm{~b}$ & $12.5 \mathrm{~b}$ & $31.7 \mathrm{~b}$ & $23.1 \mathrm{c}$ & $20.0 \mathrm{~d}$ & $10.2 \mathrm{c}$ \\
\hline $\mathrm{H}+$ Scoil & 18 & 1.00 & $38.5 \mathrm{c}$ & $6.9 \mathrm{~b}$ & $14.2 \mathrm{a}$ & $34.3 \mathrm{~b}$ & $24.3 \mathrm{~b}$ & $2.8 \mathrm{a}$ & $2.0 \mathrm{a}$ \\
\hline $\mathrm{H}+$ Action "99" & 18 & 1.00 & $20.3 \mathrm{e}$ & $4.8 \mathrm{c}$ & $7.4 \mathrm{c}$ & $30.2 \mathrm{c}$ & $22.0 \mathrm{c}$ & $31.3 \mathrm{e}$ & $21.3 \mathrm{~d}$ \\
\hline $\mathrm{H}+$ Sun-It II & 18 & 1.00 & $41.8 \mathrm{~b}$ & $7.7 \mathrm{~b}$ & $15.4 \mathrm{a}$ & $46.3 \mathrm{a}$ & $24.4 \mathrm{~b}$ & $1.4 \mathrm{a}$ & $1.0 \mathrm{a}$ \\
\hline$H+$ Agri-Dex & 18 & 1.00 & $12.5 \mathrm{f}$ & $3.8 \mathrm{~d}$ & $8.2 \mathrm{c}$ & $32.1 \mathrm{~b}$ & $21.7 \mathrm{c}$ & $23.4 \mathrm{~d}$ & $11.2 \mathrm{c}$ \\
\hline Halosulfuron $(\mathrm{H})$ alone & 27 & 0 & $18.5 \mathrm{e}$ & $5.3 \mathrm{c}$ & $8.2 \mathrm{c}$ & $31.8 \mathrm{~b}$ & $22.6 \mathrm{c}$ & $12.3 \mathrm{c}$ & $6.0 \mathrm{~b}$ \\
\hline$H+X-77$ & 27 & 0.25 & $21.2 \mathrm{e}$ & $4.6 \mathrm{c}$ & $11.0 \mathrm{~b}$ & $40.8 \mathrm{a}$ & $21.8 \mathrm{c}$ & $9.3 \mathrm{~b}$ & $3.5 \mathrm{a}$ \\
\hline $\mathrm{H}+$ Scoil & 27 & 1.00 & $34.8 \mathrm{~d}$ & $6.5 \mathrm{~b}$ & $11.8 \mathrm{~b}$ & $34.3 \mathrm{~b}$ & $24.0 \mathrm{~b}$ & $1.3 \mathrm{a}$ & $0.3 \mathrm{a}$ \\
\hline $\mathrm{H}+$ Action "99" & 27 & 1.00 & $7.5 \mathrm{f}$ & $2.0 \mathrm{e}$ & $5.8 \mathrm{~d}$ & $42.8 \mathrm{a}$ & $21.6 \mathrm{c}$ & $5.0 \mathrm{~b}$ & $2.3 \mathrm{a}$ \\
\hline $\mathrm{H}+$ Sun-It II & 27 & 1.00 & $36.9 \mathrm{c}$ & $7.2 \mathrm{~b}$ & $12.6 \mathrm{~b}$ & $41.3 \mathrm{a}$ & $23.9 \mathrm{~b}$ & $0 \mathrm{a}$ & $0 \mathrm{a}$ \\
\hline$H+$ Agri-Dex & 27 & 1.00 & $10.2 \mathrm{f}$ & $3.6 \mathrm{~d}$ & $6.4 \mathrm{c}$ & $31.7 \mathrm{~b}$ & $19.8 \mathrm{~d}$ & $14.5 \mathrm{c}$ & $7.3 \mathrm{~b}$ \\
\hline \multicolumn{10}{|l|}{ Significance $^{\mathrm{w}}$} \\
\hline Halosulfuron rate $(\mathrm{H})$ & & & ** & ** & ** & NS & NS & $* *$ & ** \\
\hline Adjuvant (A) & & & $* *$ & ** & ** & $*$ & * & $* *$ & $* *$ \\
\hline $\mathrm{H} \times \mathrm{A}$ & & & ** & NS & NS & $* *$ & NS & $* *$ & ** \\
\hline
\end{tabular}

${ }^{2}$ Purple nutsedge tubers and emerged shoots remaining in daylily containers 52 WAT).

${ }^{y}$ Halosulfuron was applied at either $18 \mathrm{~g} \cdot \mathrm{ha}^{-1}$ or $27 \mathrm{~g} \cdot \mathrm{ha}^{-1}$ to all treatments except nontreated control and nutsedge control. Nontreated control containers were manually kept free of weeds and nutsedge control containers were manually kept free of weeds except purple nutsedge.

${ }^{x}$ Mean separation in columns by Duncan's new multiple range test, $P \leq 0.05$.

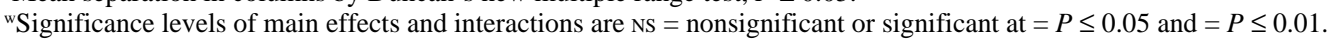


1993; Manthey et al., 1992; Prendeville and Warren, 1975). The capacity of purple nutsedge to reproduce abundant tubers from the initial inoculation of five tubers/container is evidenced by the nutsedge control treatment in June 2000 (79.8 tubers/container). Having only a few tubers remaining viable would necessitate a follow up halosulfuron treatment to emerging shoots in late spring to suppress purple nutsedge.

All treatments reduced daylily flower numbers (Table 2). The presence of untreated nutsedge also caused a $54.6 \%$ reduction in flower production. Halosulfuron reduced flower numbers with or without adjuvants. At the lower halosulfuron rate tested, daylily flowering was reduced the least when combined with $\mathrm{Scoil}^{\circledR}$ (34.3\% flower reduction) or Sun-It II ${ }^{\circledR}$ (28.7\% flower reduction) adjuvants. In addition to flower number reductions among daylily, the number of flowering scapes was reduced by all treatments. Less reduction occurred when halosulfuron was combined with either Scoil ${ }^{\circledR}$ or Sun-It II ${ }^{\circledR}$, or with halosulfuron at $18 \mathrm{~g} \cdot \mathrm{ha}^{-1}$ combined with $\mathrm{X}-77^{\circledR}$. Number of flowering scapes produced by liriope was not affected by the combination of Scoil ${ }^{\circledR}$ or Sun-It II ${ }^{\circledR}$ adjuvants with halosulfuron at $18 \mathrm{~g} \cdot \mathrm{ha}^{-1}$. By contrast, both Action "99"® and Agri-Dex ${ }^{\circledR}$ severely reduced the number of flowering scapes of liriope, regardless of halosulfuron rate. The number of flowering scapes was also reduced in daylily. However, scapes were longer in plants receiving the higher halosulfuron rate in combination with $\mathrm{X}-77^{\circledR}$ or Action"99" ${ }^{\circledR}$ or either rate of halosulfuron plus Sun-It II ${ }^{\circledR}$.

Our data have shown that purple nutsedge can be suppressed in containerized liriope and daylily without permanent phytotoxicity or inhibition of growth when halosulfuron is combined with a methylated seed oil-based adjuvant. Reduced flowering can be expected the following growing season with plants treated with halosulfuron and should be anticipated when transplanting to a landscape environment. No differences in purple nutsedge control were observed between halosulfuron rates combined with the methylated seed-oil adjuvants, but the $27 \mathrm{~g} \cdot \mathrm{ha}^{-1}$ rate combined with these adjuvants inhibited growth of both landscape species and resulted in higher phytotoxicity ratings for daylily, but not for liriope at 8 WAT.

\section{Literature Cited}

Bachman, G., C. Wilson, and T. Whitwell. 1995. Tolerance of containerized landscape plants to the postemergence herbicides Stinger, Manage and Basagran. J. Environ. Hort. 13:129-132.

Banks, V.E. and L.R. Oliver. 1984. Soybean oil and postemergence herbicides. Proc. Southern Weed Sci. Soc. 37:92.

Barry, G., G. Kishore, S. Padgette, M. Taylor, K. Kolacz, M. Weldon, D. Re, D. Eichholtz, K. Fincher, and L. Hallas. 1992. Inhibitors of amino acid biosynthesis: Strategies for imparting glyphosate tolerance to crop plants, p. 139145. In: Singh et al. (eds.). Biosynthesis and molecular regulation of amino acids in plants. Am. Soc. Plant Physiologists, Rockville, Md.

Bendixen, L.E. and U.B. Nandihalli. 1987. Worldwide distribution of purple and yellow nutsedge (Cyperus rotundus and C. esculentus). Weed Technol. 1:61-65.

Cantwell, J.R. and G. Kapustra. 1986. Application of bentazon and sethoxydim in soybean oil with rotary atomizers. Agron. J. 78:478-482.

Dowler, C.C. 1994. Weed survey southern states. Proc. Southern Weed Sci. Soc. 47:279-299.

Grichar, W.J. and D.C. Sestak. 2000. Effect of adjuvants on control of nutsedge (Cyperus esculentus and $C$. rotundus) by imazapic and imazethapyr. Crop Protection 19:461-465.

Harrison, K.S., L.M. Wax, and L.E. Bode. 1986. Influence of adjuvants and application variables on postemergence weed control with bentazon and sethoxydim. Weed Sci. 34:462466.

Hauser, E.W. 1962. Establishment of nutsedge from space-planted tubers. Weeds 10:209-212.

Helson, V.A. and W.H. Minshall. 1962. Effects of petroleum oils on the carbon dioxide uptake in the apparent photosynthesis of parsnip and mustard. Can. J. Bot. 40:887-896.

Hix, R.L., C.D. Pless, D.E. Deyton, and C.E. Sams 1999. Management of San Jose scale on apple with soybean-oil dormant sprays. HortScience 34:106-108

Hurt, R.T. and W.K. Vencill. 1993. Efficacy of single early postemergence treatments of imidazoline on yellow and purple nutsedge (Cyperus esculentus L. and Cyperus rotundus L.) with ornamental tolerance. Proc. Southern Weed Sci. Soc. 46:363.

Hurt, R.T. and W.K. Vencill. 1994. Evaluation of three imidazolinone herbicides for control of yellow and purple nutsedge in woody and herbaceous landscape plants. J. Environ. Hort. 12:131-134

Johnson, W.T. 1985. Horticultural oils. J. Environ. Hort. 3:188-191.

Jordan, D.L. 1996. Adjuvants and growth stage affect purple nutsedge (Cyperus rotundus) con- trol with chlorimuron and imazethapyr. Weed Technol. 10:359-362.

Khan, R.A. and W.T. Molin. 1997. Translocation of 14C-halosulfuron-methyl and 14C-glyphosate in purple nutsedge (Cyperus rotundus L.). Weed Sci. Soc. Amer. 37:122. (Abstr.)

Kirkwood, R.C. 1993. Use and mode of action of adjuvants for herbicides; a review of some current work. Pesticide Sci. 38:93-102.

Manthey, F.A., R. Matysiak, and J.D. Nalewaja. 1992. Petroleum oil and emulsifier affect the phytotoxicity of imazethapyr. Weed Technol. 6:81-84.

McDaniel, G.L., D.C. Fare, W.T. Witte, and P.C. Flanagan. 1999. Yellow nutsedge control and nursery crop tolerance with Manage as affected by adjuvant choice. J. Environ. Hort. 17 (3):114 119.

McWhorter, C.G. 1992. The use of adjuvants. p. 10-25. In: R.A. Hodgson (ed.) Adjuvants for herbicides. Weed Sci. Soc. Amer. Champaign, Ill.

Molin, W.T., A.A. Maricic, R.A. Khan, and C.F. Mancino. 1999. Effect of MON 12037 on the growth and tuber viability of purple nutsedge (Cyperus rotundus). Weed Technol. 13:1-5.

Nalewaga, J.D. and G.A. Skzypczak. 1986. Adsorption and translocation of fluazifop with additives. Weed Sci. 34:572-576.

Prendeville, G.N. and G.F. Warren. 1975. Spreading and penetration of herbicides dissolved in oil carriers. Weed Res. 15:233-241.

Rao, J.S. 1968. Studies on the development of tubers in nutgrass and their starch content at different depths of soil. Madras Agr. J. 55(1):19-23.

Reihl, L.A. and R.T. Wedding. 1959. Effects of napthenic and paraffinic petroleum composition at a comparable molecular weight or viscosity on photosynthesis of Eureka lemon leaves. J. Econ. Entomol. 52:883-884.

Ross, M.A. and C.A. Lembi. 1985. Applied weed science. Burgess Publishing Co., Minneapolis, Minn.

Stoller, E.W. and R.D. Sweet. 1987. Biology and life cycle of purple and yellow nutsedges (Cyperus rotundus and C. esculentus). Weed Technol. 1:66-73.

Vencill, W.K., J.S. Richburg, III, J.W. Wilcut, and L.R. Hawf. 1995. Effect of MON-12037 on purple (Cyperus rotundus) and yellow (Cyperus esculentus) nutsedge. Weed Technol. 9:148152.

Wedding, R.T., L.A. Riehl, and W.A. Rhoads. 1951. Effect of petroleum oil spray on photosynthesis and respiration in citrus leaves. Plant Physiol. 28:269-278.

Wills, G.D. and G.A. Briscoe. 1970. Anatomy of purple nutsedge. Weed Sci. 18:631-635.

Zar, J.H. 1984. Biostastistical Analysis. 2nd ed. Prentice-Hall, Englewood Cliffs, N.J. 